\title{
Copyright Royalty of Book Publishing as Collateral Objects
}

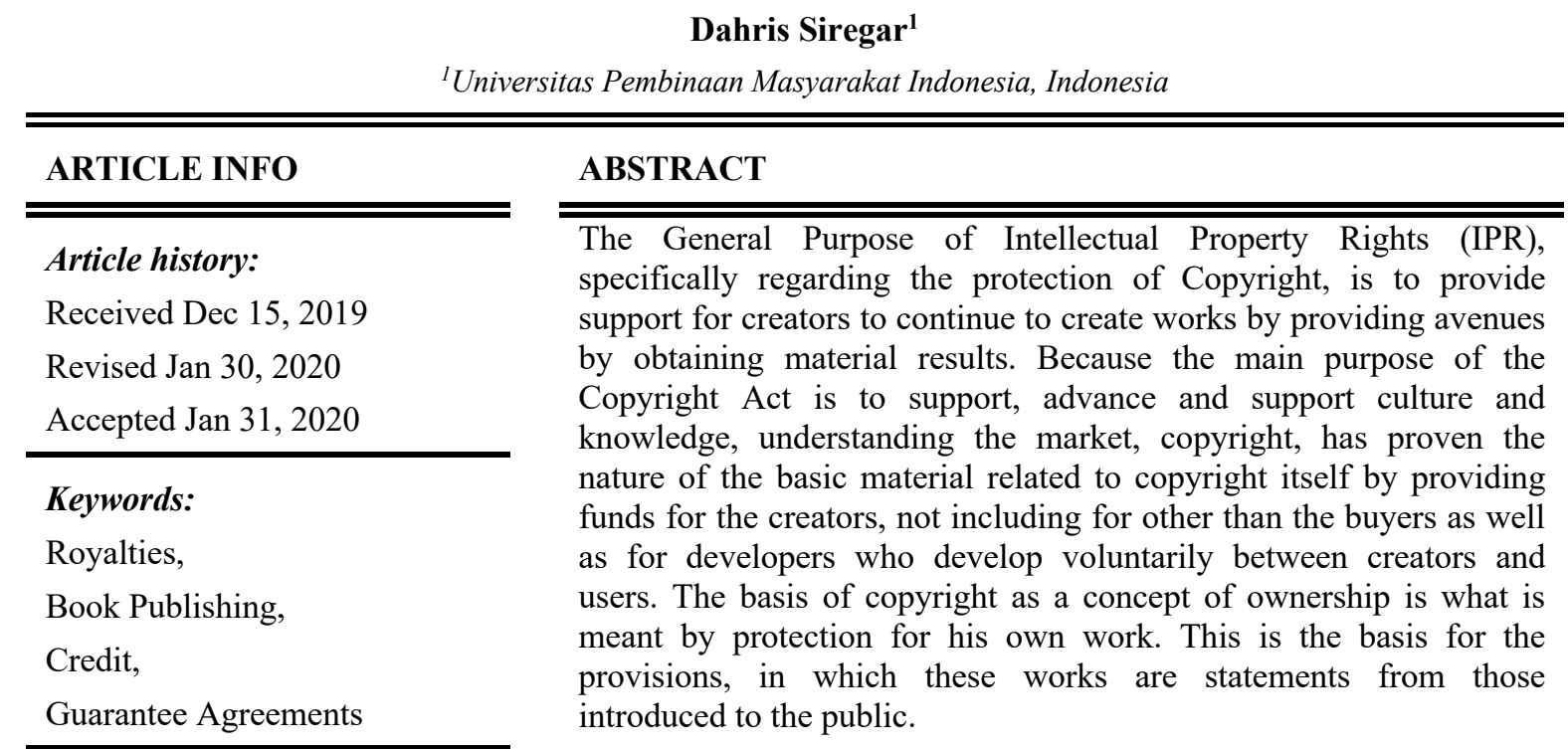

Clonflict of Interest:

None

Funding:

None

Corresponding Author: Dahris Siregar, Senior Lecturer at Universitas Pembinaan Masyarakat Indonesia, Email: dahrisganteng@gmail.com Phone No.: +6281375473616.

(c) $\bigodot_{\text {BY }}$ () SA This is an open access article under the CC BY-SA 4.0 international license.

\section{Introduction}

In the framework of legal development in Indonesia as defined in Garis-garis Besar Haluan Negara (GBHN) through Ketetapan Majelis Permusyawaratan Rakyat Republik Indonesia No.IV/MPR/1999 about Tentang Garis-Garis Besar Haluan Negara year of 1999-2004, and to encourage and protect the creation, dissemination of cultural products in the fields of science, art, and literature and to accelerate the growth of intelligence in the life of the nation in the Republic of Indonesia Pancasila and Undang-undang Dasar 1945, then there is a need for legal protection on copyright. The protection of the Law is intended as an attempt to create a better climate for growth and a growing passion for science, art and literature at the heart of Indonesian society.

In Indonesia, the law that protects copyright is the 6th law of 1982 on copyright, as modified by the No. 7 of 1987 law on changes to the copyright law of the 6th, 1982, and the last has been amended by law No. 12 of 1997 on the amendment of the No. 7 of 1987 Act on copyright and some of its rules of practice. And on July 29, 2002, the new Law No. 19 of 2002 on Copyright and the passing of Law No. 28 of 2014 About Copyright.

Every human being on this earth has the absolute right to the creation that they have created or that they have created in the form of something or in the form of ideas. The absolute right that is due to every creation of the human mind is what is called copyright, which is the right that a person has immediately after he or she has successfully created the creative idea in his or her mind in the form of ideas. 
Any brilliant and creative ideas created by an individual or group of people as a form of useful human intellectual ability and good impact on various aspects need to be acknowledged and protected, so that brilliant and creative ideas that have been created are not claimed or was plowed by another party. For that, there is a need for a container that can assist and uphold these brilliant and creative ideas. At the international level of organizations covering the HaKI (Intellectual Property Rights) is WIPO (World Intellectual Property Organization).

As many cases of copyright infringement occur in Indonesia, it is certainly an issue that concerns the creators of a work. A form of creativity one should cherish, instead, it serves as a chance to benefit unscrupulous parties.

But more and more problems are arising over these copyright issues. There is still a lot of confusion as to how the copyright has arisen, who has the right to intellectual property that has already been created because many people still do not understand how the legal system in HaKI regulates this copyright.

It seems that piracy in Indonesia of Intellectual Property Rights (HaKI) has caused many manufacturers and owners or owners of HaKI to be harmed. It is undeniable that pirated products are the most sought after and most sought after by the Indonesian community.

Indonesia is a country of ethnic / tribal and cultural diversity and richness in the arts and literature with its development requiring copyright protection of intellectual property born of that diversity. Developments in trade, industry, and investment have been so rapid that they require increased protection for creators and owners of related rights while keeping the interest of the public at large.

Infringement on individual or group intellectual property alone violates the rights of the intellectual property owner. If they want to be dramatized, the violation of the intellectual or intellectual property of a person or group is equivalent to disregarding the originality of a work. That is another word of the "cleverness" that is being misunderstood. It is these principles that are the basis for the existence of the term "HAKI" in Indonesia.

The works of art in the field of science, art and literature are basically human works of human intellect that are born as embodiments of the quality of their taste, will and purpose. Such works in addition to having meaning as works that are physically present in the human heart, also present as a means of fulfilling the inner needs of everyone. The more, the bigger, and the higher the quality of one's work, the more it will give value to the dignity and dignity of the person who gave birth to it and the human life in general.

Intellectual ability refers to the intellect, the intellect, the imagination, the imagination, or the result of human thought or the creation of human mind. RAW protects intellectual property owners in a fairly exclusive right. That exclusive right is a rule against intellectual property infringement. In general, rights include copyright, patent, trademark, and other intellectual property rights.

Indonesia in fact has a lot of creative creativity, not to mention the fact that there are some societies with mental plagiarism.

Today, cases of copyright infringement in Indonesia are increasing. This case should be a major case that should be resolved immediately, not considered trivial. Most people may not see this as a major issue, so the issue is not immediately resolved and penalizes the copyright infringement.

In addition, a creation is not simply born out of the desire, feeling, instinct and the inner satisfaction of its creator. The work is also born out of a desire to devote to a value or something that is admired by the environment or even to the people around it.

It can finally be said that copyright is a special right given by the government to someone who has created something based on his thinking or expertise in the fields of science, art and literature.

In accordance with Law No. 6 of 1982, which was later amended by Law No. 7 of 1987 on Copyright, it can be said that the object of Copyright is works in the field of science, art and literature and artistic works. After the Law No. 7 of 1987, there was further refinement with the enactment of the Republic of Indonesia Law No. 19 of 2002 on Copyright. By Law No. 19 In 2002, the definition of copyright was the exclusive right of the creator or assignee to declare or reproduce his creation or to authorize it without subtracting any restrictions in accordance with applicable laws.

This indicates that the copyright can only be owned by the creator or the assignee. Only the name of the socalled rights holder may use the copyright and he or she is protected in the exercise of his or her rights against any other subject that interferes with or uses it in a manner not permitted by law.

Pursuant to the 28th Law of the Year 2014 on Copyright, the definition of Copyright is Copyright is the exclusive right of a creator who automatically arises on a declarative principle after a creation has been made manifest without reducing the restrictions in accordance with the law. 
The work needs to be protected by the law, the Government of the Republic of Indonesia has promulgated the 28 Year 2014 Law of Copyright (hereinafter UUHC) which is an instrument or legal instrument to guarantee copyright protection, one of which is a book. UUHC provides better legal protection for creators. This means that copyright is an intellectual property in the fields of science, art, and literature that has a strategic role in supporting the development of the nation and promoting the general welfare as enacted by the Constitution of the Republic of Indonesia of 1945 (hereinafter UUD 1945).

The book as an object of property rights Intellectual, the protection stipulated in legislation. Legislation Intellectual Property Rights is the most recent Copyright Law Number 19 Year 2002 in determining violations, Copyright Act establishes the existence of copyright infringement in case acts committed against the copyrighted work whose copyright is exclusively owned by others without the knowledge or permission of the owner of such rights of others.

The protection of the works of authorship from many acts has been done since the 17th century. The rule was issued by the English parliament called "The Statue Of Anne" which brought and greatly influenced the position of the creator who created a work of writing based on his intellectual ability.

The issue of Intellectual Property Rights (HaKI) has become popular in Indonesia especially since the introduction of the term creative industry and the rise of inter-state political disputes over protection of Traditional Knowledge and Traditional Cultural Expressions. In question, the issue of HaKI protection is still considered foreign to culture in Indonesia. Thus, a deep understanding of the philosophical foundation and history of the development of HaKI protection as a medium for the Government to formulate policies appropriate to Indonesia's national development is required.

Qualitative research methods with primary sources of secondary data were conducted in this study, with a descriptive purpose. Through this study, it is concluded that to date HaKI protection is needed in Indonesia in order to improve the welfare of the people. This is because the need for HaKI protection is a fundamental human trait that is based on the desire to earn a living, a decent living and economic independence.

However, various policy, social and cultural adjustments are needed to improve the effectiveness and efficiency of HaKI protection in Indonesia. The reason for this view is that there is a suspicion that the issue of poverty and social and cultural conditions of society exert a huge influence on the acceptability and quality of law enforcement in the field of Haki protection.

The protection works to protect the work of the invention from the act of unauthorized printing. The writing here refers to any work other than music (song lyrics) or drama (script), written, oral, or singing, as well as a work of a table, computer program, or design prepared for a computer program or a source of data. 1 Books in the fields of science, art and literature as UUHC-protected works, in the process of creation require the sacrifice of mind, time, cost and energy.

Such a great sacrifice, of course, makes the work produced economically valuable and worth it. A legal device is required to protect the work and to ensure that the creator can act, control and enjoy the work exclusively. This shows that legal protection is in the best interests of the rights owner.

The reproduction of a work (book) must have the permission of the creator or copyright holder. This is stated in Article 1 number 1 of the UUHC which states: "Copyright is the exclusive right of a creator who automatically arises under a declarative principle after a creation has been made manifest without reducing the restrictions in accordance with the rules of the law".

The question is, in Indonesia itself HaKI protection does not yet seem to be a solid national consensus. This condition can be seen from the fact that in the 2010 Political and Economic Risk Consultancy (PERC) 2 survey that Indonesia is the first ranked country for HaKI violators in Asia3. In fact, the Ministry of Law and Human Rights has elegantly acknowledged that Indonesia's understanding of HaKI is still minimal. Thus, the concept and legal system of HaKI in general can still be said to be "foreign" in the context of Indonesian culture. The question then becomes more complex when it is associated with PT and EBT that are closely linked to the culture of a particular traditional group of people, as it involves an effort to establish a law of generality, or a rule of law that is unprecedented4. To understand whether and to what extent the concept and regime of HaKI is acceptable in Indonesia, within the framework of PT and EBT protection, it is necessary to first understand the philosophical underpinnings and historical background of the development of HaKI protection.

However, to date, there has been no literature on HaKI published in Indonesian that delves deeper into the philosophical underpinnings and developmental history of HaKI protection. Through the study of this primary source of data, it is revealed in deep arguments about the origin of the concept and regime of HaKI and its brief history of development. Therefore, from the point of view of its purpose, this study is descriptive. In addition, this research method is qualitative as it is generally based on the analysis of the 
views of the most influential philosophers in the development process of HaKI protection and the views of several experts who interpret the views of the philosophers. Intellectual property is a translation of the English term "intellectual property" by the World Intellectual Property Organization (WIPO). Symbols, names, images and designs used in trading activities5. Meanwhile, Intellectual Property Rights (HaKI) as a translation of the same language Intellectual Property Rights (IPR) is defined as “... the rights giventopersons over the creations of their minds. They usually give the creator an exclusive right over the use of his / her creation for a certain period of time "6. Others say that the law regarding the protection of HaKI is at the core of the struggle of the parties who demand the mastery of their works against others who wish to separate the creator's power from his creation.

A detailed description of the so-called "creation of mind" is stated in Article 2 of the viii Agreement Establishing the World Intellectual Property Organization, which is:

1. Written works, art and works in the field of science;

2. Performances performed by artists, through sound recording and broadcasting;

3. Creation of something new (invention) in various fields;

4. Discovery or discovery for the first time in science;

5. Industrial design;

6. Trademarks, service marks, commercial names and titles;

7. Protection against fraudulent competition; and

8. All other rights arising from intellectual activities in the world of industry, science, writing or art. It can be interpreted that these types of RISK are not limited to what is currently known, but they can mean unprecedented or previously known types.

The most common form of copyright infringement is duplication by way of reproduction without the consent of the creator or copyright holder commonly known as piracy. There are, of course, many other forms of copyright infringement, one of which is a royalty payment for a less well-known author of the book's works, for so far the public's view of copyright protection has only focused on efforts to eradicate copyright.

The provisions of Article 80 of the UUHC, clarify:

(1) Except as otherwise provided, the copyright holder or the owner of the Related Rights reserves the right to grant the License to another party under the written agreement to perform the act as intended in Article 9 paragraph (1), Article 23 paragraph (2), Article 24 paragraph (2), and Article 25 paragraph (2).

(2) The License Agreement as referred to in paragraph (1) shall be for a period of time and shall not exceed the term of Copyright and Related Rights.

(3) Except as otherwise expressly provided, the execution of the act as referred to in paragraph (1) shall include the obligation of the Licensee to grant royalties to the copyright holder or related rights holder for the duration of the license.

(4) The determination of the royalties as referred to in paragraph (3) and the procedure for granting royalties shall be based on the license agreement between the copyright holder or the related rights holder and the licensee.

(5) The magnitude of the royalties in the license agreement must be determined in accordance with the prevailing practice of law and the elements of justice.

The meaning of the License is in line with copyright as an exclusive and economic right, the creator / copyright holder has the right to grant to another party the right to exercise his or her economic rights and his or her license cannot be revoked from the issue of profitability of copyright use. Granting permission from the creator / copyright holder to another is called a license.

In Article 1 of 20 of the Copyright Act 2014, the License is the written permission given by the copyright holder or related rights owner to another party to exercise economic rights over their creation or product rights with respect to certain conditions.

The legal relationship between the copyright owner and the copyright holder in relation to the copyright license is bound by the agreement, namely.

a. Includes obligatoire agreements

Essentially, licenses in the field of Intellectual Property are not just a matter of granting permission, but they do create reciprocal rights and obligations between one and the other. For that reason licenses are a binding agreement for them. In legal science such agreements are called obligatoire agreements. 
A copyright license agreement is also a consensualism agreement, as it is subject to a consensus or a consensus. Then the birth of a copyright license agreement follows the principle of freedom of contract, that anyone can make any agreement, at any time, and contain any source that does not conflict with law, practice, and compliance. The restrictions imposed by Law No. 28 of 2014 on Copyright in freedom of license agreement are as stated in Article 82 that: the license agreement should not contain provisions that result in the loss of the Indonesian economy; the contents of the license agreement are prohibited in accordance with the provisions of the legislation; a license agreement shall not constitute a means of removing or depriving the entire copyright of its creator.

b. Must fulfill the legality of the agreement

In Article 80 of the Copyright Act 2014, it is stated that a copyright license is made on a contractual basis. Because it is a form of agreement it is obliged to comply with the conditions set out by Article 1320 of the Civil Code, namely:

1. Have a word of agreement have skills

2. Certain things

3. A lawful cause

c. The agreement must be in writing

In addition to meeting the four requirements of Article 1320 of the Civil Code, a copyright license agreement must also be in writing. This written condition is expressly stated in Article 1 number 20, which is in the words 'written permission' meaning that this license agreement must be in writing non-verbal.

In accordance with the provisions of Article 83 of Law No. 28 of 2014, a license agreement is required to be made to the Directorate General of Intellectual Property Rights which is then included in the General Register by paying the full costs as determined by the Minister's Decree. However, if the license agreement is not entered into, then the license agreement has no legal effect on the third party.

The royalty arrangement contained in the provisions of Article 80 paragraph (3) governs the obligation of granting royalties to the copyright holder by the licensee. Article 80 paragraphs (4) and (5) govern the amount or amount of royalties payable to the copyright holder by the licensee based on the agreement of both parties in accordance with the professional organization agreement.

There are 2 (two) parties in publishing a book that need each other: the author (author) who needs the publisher to publish the manuscript, and the publisher who needs the author's script for the purpose of their business activities. The legal relationship between the author and the publisher is in the form of a book publishing agreement. A book publishing agreement is in fact a copyright transfer of a writer's work to a publisher. The creator is transferring the copyright for the purpose of acquiring the royalty while the publisher receiving the copyright transfer seeks to profit from the sale of the books.

It redirects the copyright to a book and the copyright remains in the hands of the author as long as the author does not submit his or her copyright to the publisher. On the other hand with the publication of the book, the author will receive royalties from the book's publication. However, in practice there are often royalty payments to authors who do not comply with the agreement. This is due to the lack of understanding of copyright and UUHC related party in the book publishing industry, as well as the attitude and desire to profit easily by infringing the copyrights of others.

It should, however, be required that every book of the books should have the knowledge and consent of the author as the owner and copyright holder as it will affect the amount of royalties that the author must pay or pay. In this case the publisher requires honesty when printing the book and is prohibited from reprinting or reproducing beyond the knowledge of the author and providing accurate information about the sale, as the author cannot control the book being printed and how much it has sold. In practice, however, many publishing and selling books by outside publishers are promised without the knowledge of the author clearly detrimental to the author in connection with the payment of royalties.

In connection with the implementation of the agreement, which is also intended to protect the interests of authors and publishers, the common issue is the question of the sale of books that are the object of the agreement. Authors on the one hand often ask for a book sale report published by the publisher in this case related to the royalties the author will receive. On the other hand publishers feel that they have fulfilled their obligations with respect to book sales reports by simply presenting sales reports that are usually quarterly or semiannual. This policy makes writers often dissatisfied and at the risk of manipulating sales data. 
In connection with royalty in the copyright of the book publishing cannot be extinguished, the agreement has become an integral part of human life. Therefore in the business world, business partnerships are poured into an agreement that will eventually underpin the business.

Agreements in the business world are usually made in writing, or so-called contracts. A contract made in a business relationship has the nature of a contract that is not a legal consequence. Because a contract is a contract between the parties with binding legal consequences, it is in the sense of agreement even though the terms of the contract are not necessarily a contract because the agreement is not exclusive as a term of an alliance in business.

A covenant is an "act," that is, a legal consequence. An agreement is a legal act to obtain a set of rights and obligations called an accomplishment. The legal act of the treaty is the act of doing things, as described in the preceding paragraphs such as sale, rent, rent, and something else. Another opinion expressed by M. Yahya Harahap, is that: A treaty is a legal relationship involving the law of wealth of two (2) or more persons, which grants one party the rights and obligations to the other for an accomplishment.

An agreement can also be interpreted as an act that binds 2 (two) or more persons. The Agreement may be oral or written. But for something serious and important, which could potentially cause a dispute in the future, whether the agreement is in writing, can be an authentic piece of evidence that can help later in the day if a dispute arises.

An agreement is made up of several parties; these parties may be individuals, legal entities, or persons with legal entities. Both are subjects of law, namely, those who can do legal things. Where the law is said to carry out acts that have legal consequences and are responsible for it.

The purpose of the treaty itself is to regulate the legal relationship and to create a set of rights and obligations that bind the parties to the agreement. In addition, the agreement also seeks to create justice for the parties and clarity in writing which will assist the parties in discharging their rights and obligations once the agreement is entered into.

From the foregoing, the agreement may be oral or written. For example, verbal agreements such as direct dealings, face to face and absence of black on white. It is usually based on trust between the parties concerned while a written agreement is usually called a letter of agreement. A treaty itself can be interpreted as a letter containing a mutual agreement binding on the parties concerned, that is, the agreement on the rights and obligations of each party binding each other to do something or not to do something. The contents of the treaty itself must be in line with what both parties want, in order to create a shared justice for the sake of mutual advantage.

Article 50.b of Law No. 5 of 1999 The Prohibition of Monopoly Practices and Unhealthy Competition ("Anti-Monopoly Law") exempted all agreements relating to intellectual property rights, such as licenses, patents, trademarks, copyrights, industrial product design, electronic networks unified and trade secrets, and franchise related agreements. From the point of view of the Intellectual Property Rights Act, the above Article is viewed (i) specifically against the provisions of the law in the field of Intellectual Property Rights which specifically prohibits the making of agreements in the field of Intellectual Property Rights that are detrimental to the economy Indonesia and potentially create monopoly practices and competition for unhealthy businesses; and (ii) is generally contrary to the provisions of Article 1340 of the Indonesian Civil Code (Het Burgerlijk Wetboek voor Indonesia, Staatsblad 1847-23) which reads:

Overeenkomsten zijn alleen van kracht tusschen de handelende partijen.

Dezelve kunnen aan derden niet ten nadele verstrekken; zij kunnen aan derden geen voordeel aanbrengen, dan alleen in het geval voorzien bij artikel 1317.

The translation in English is as follows:

The agreements only bind the parties who made them.

These agreements may not result in any third party loss; such agreements may not be of any benefit to any third party except in the case of regulations in the field of Intellectual Property Rights which specifically prohibit the making of agreements in the field of Intellectual Property Rights that could harm the Indonesian economy and create monopolies and unhealthy business competition are as follows:

Article 71.1 of Law No. 14 of 2001 Regarding Patents:

The License Agreement (in the field of Patents) shall not contain provisions, either direct or indirect, that may harm the Indonesian economy or impose restrictions on the control and development of technology in general and in connection with the inventions in which such Patents are in particular. Article 47.1 of Law No. 15 Year 2001 About Brands: The License Agreement (in the field of Brands) may not contain direct or 
indirect provisions that could adversely affect the Indonesian economy or impose restrictions that impede Indonesia's ability to master and develop technology generally

Article 47.1 of Law No. 19 of 2002 About Copyright:

The License Agreement (in the field of Copyright) does not prohibit provisions that could harm the Indonesian economy or contain provisions that result in unprofessional competition as set forth in applicable legislation.

Article 36.1 of Law No. 31 Year 2000 About Industry Design:

The License Agreement (in the field of Industrial Design) is prohibited to contain provisions that could be detrimental to the Indonesian economy or to contain provisions that would result in unhealthy business competition as stipulated in applicable legislation.

Article 28.1 of Law No. 32 of 2000 on Integrated Circuit Layout Design:

The License Agreement (in the area of Integrated Circular Layout Design) is prohibited to contain provisions that could be detrimental to the Indonesian economy or to impose conditions that would result in unhealthy business competition as set forth in applicable legislation.

Further, the word "related" in Article 50.b of the Anti-Monopoly Law makes not only agreements that are specifically in the field of Intellectual Property Rights excluded from the enforcement of the provisions of the Anti-Monetary Law The monopoly, but all other agreements in the realm of (all) matters relating to Intellectual Property Rights, are also excluded from the enforcement of the Anti-Monopoly Law.

These provisions can be multi-interpretive, so one can interpret a joint venture agreement that, possibly, rests on the establishment of a limited partnership in the field of foreign capital investment, which in the course of its business activities will depend on technology, know-how and the intellectual property rights of either party to the joint venture agreement, such as a foreign party; and to carry out such activities by signing an intellectual property license agreement, franchise agreement, technical assistance agreement, management contract and so on, what may be called in reference to the incorporation by reference in the joint venture agreement, the joint venture agreement will be excluded from the enforcement of the Anti-Monopoly Law as it is considered in connection with the Intellectual Property Rights.

Therefore, the agreement is very much needed by the business owners, so use it to ensure legal certainty. One business that requires an agreement is to publish books. Books are a work of art that must be protected. A legal device is required to protect the work and to ensure that the creator can act, control and enjoy the work exclusively. This shows that legal protection is in the best interests of the rights owner. The act of reproducing the creation (book) must have the permission of the creator or copyright holder (author). According to Harris Munandar and Sally Sitanggang, copyright is: "the exclusive or exclusive right of the creator or copyright holder to regulate the use of the work or the production of certain ideas or information".

Copyright is a form of ownership that gives the holder (creator) the exclusive right to control the use and use of an intellectual creation, such as the creation specified in the copyright category, such as literature, drama, music and artwork as well as sound recordings, movies, radio and television broadcasts, as well as many published papers through publications (publications).

\section{Results And Discussion}

The enactment of copyright laws is intended to protect authors and publishers from harm to one another. In this case there are two parties who need each other: the creator (author) who needs the publisher to publish his work (book) and the publisher who needs the author (book) work for his business.

It takes a long path when the author submits a workbook to a publisher who is expected to publish his book. The process / process for submitting a work to be published as applicable books in existing publishers is usually the same.

First, after the author submits his / her work / book scenario, the publisher will accept and then be acted upon by the responsible section. In this section the work will be researched, tested, reviewed, and learned, whether the work is original and not plagiarism, whether the work meets the criteria for publication, and whether the work will benefit or disadvantage the publisher. In other words the work will be tailored to the needs of the publisher as well as the needs of the target readers when the book is published.

Once the process is done, the responsibility team will consider the work with their team and if the publisher is interested in publishing it, the publisher will contact the author to formulate an agreement covering the publishing and duplication of books and the amount of pay the author will receive. 
The agreement formulated the rights and obligations of parties, authors and publishers. This agreement is important because it will serve as the basis for the copyright protection that the author has for his work, as mandated in HaKI in this regard.

In practice, however, the relationship between the author as the author and the publisher as the publisher of the book is unbalanced. There are some cases where a book publisher exploits a book's copy by means of a copy or publication of the manuscript without the author's permission or without the knowledge of the author. Even more so now is the place where books are published, which of course requires extra attention so as not to harm one another.

The cooperation between the two is very important. The author would not publish his work without a book publisher. On the other hand, the publisher of the book would not be known to print the book without the author. They both need each other. They should be proportional, measurable, legally binding, and mutually beneficial.

The collaboration between the author and the publisher of the book should be built on professional principles, not just marriage. Bookwriters and book publishers in this professional relationship have their own rights and obligations. Authors will need a publisher of books, in publishing their work and in developing a readers' market. The publisher of the book, however, needed works to be printed and marketed to develop his corporate system.

How to publish a book is generally some kind of collaboration that can be made between the author and the publisher of the book. The system relies on each party to choose one of their preferred types of cooperation. First, publishers and authors can make a buy or sell script. The author can do this by offering his manuscript to the publisher. The issuer will then provide the price in the specific nominal calculation as agreed.

There are benefits and disadvantages for authors in the process of publishing this type of collaborative book. Writers will benefit from getting results early. He also earns money when a transaction is made. On the other hand, writers can also be at a loss. He no longer owns the copyright for switching to the publisher, though his name will still be included in the script. The author also suffered a loss when he had no effect on the book's sales, though his work was sold and printed many times.

This kind of collaboration is beneficial in the short term. It's a lot more practical. But in the long run, this system of cooperation creates inequality on the part of the author. Not many publishers use this system. Break or buy a script is usually done in a special script case. In addition, publishers of books that operate this system are usually publishers who are not yet ready to manage their long-term company-oriented.

\section{Conclusion and Recommendation}

\subsection{Conclusion}

The general purpose of the Intellectual Property Rights (HAKI), in particular the protection of Copyright, is to provide an incentive for creators to continue to produce works by providing a means of obtaining material. While the primary purpose of the Copyright Act is to promote, promote and disseminate culture and knowledge, the copyright market has allowed the basic properties of public property to be derived from the copyright itself by providing compensation to the creator, but not including in addition to buyers and sellers who develop voluntary exchanges between creators and users.

The basic tenet of copyright as a concept of ownership is that it allows for protection of its own work. This is the basis of the provision, in which the works are an expression of the idea presented to the public. These owners are part of the range of information in which the flow of non-stop information can be important to the general public. Thus, copyright guarantees that creators not only keep their work under control, by preventing unauthorized reproduction, but also assuring that their creators can benefit from their intellectual work. This can be considered an incentive to publish his work. Copyright also acts as a compensation for the financial risk of the owner's acceptance by publishing his work. Without the protection of copyright, a creator may refuse to publish his work, which, in the end, may not be enjoyable.

The benefits that creators enjoy through copyright protection are problematic. The full right of the owner to anyone who wishes to copy his work is sometimes in conflict with the public interest, for example in his role and interests in the social, political, educational and cultural spheres. Some say that information and works should be considered public, so they are no longer required by the Copyright Act. The right to control access to a public piece of work before it is published does not pose a problem in the freedom of speech, but the publisher may control that access upon publication. This explains why copyright has historically been considered a form of monopoly that should be strictly interpreted to serve the public interest of copyright holders. 


\subsection{Recommendation}

Based on the research results in the dissertation writing that the authors have outlined in the above conclusions, the authors also have suggestions and expectations that will be outlined in the following points:

a) The system of royalty in book publishing consists of the first elements, the subject matter of which the author or author is the creator and the publisher as the copyright holder. The second element, the agreement meant the implementation of royalty payments on book publishing based on the agreement laid down in the treaty, is a license agreement that begins with the offering or negotiation of the subject matter of the author and publisher of books in the book publishing cooperation. Third, the object of the book publishing system's royalty system is to exploit the economic rights of the book's creators. The fourth element is that payments in the book publishing royalty system are made in accordance with the agreement.

b) The control over the number of books published, printed, and sold cannot be accurately ascertained by the author as the author who has given the publisher permission to publish his work in the form of a book. Regulating the volume of books that are published, printed and sold cannot be done by the author because the mechanism for publishing books up to the time of marketing is so complicated. Therefore, in this matter of cooperation, trust is the foundation.

\section{References}

Abdul Kadir Muhammad, Kajian Hukum Ekonomi Hak Kekayaan Intelektual, Bandung: Citra Aditya Bakti, 2001.

Achmad Ali, Teori Hukum dan Teori Peradilan Termasuk Interpretasi Undang-Undang, Kencana Prenada Media Grup, Jakarta.

-, Menguak Tabir Hukum (Suatu Kajian Filosofis Dan Sosiologi), Gunung Agung, Jakarta, 2002.

Ahmad M. Ramli, Cyber Law dan Haki, Bandung, 2004.

Agus Yudha Hernoko, Hukum Perjanjian (Asas Proporsionalitas dalam Kontrak Komersial), Kencana, Jakarta, 2011.

Altbach, Philip G. 2000. Bunga Rampai Penerbitan dan Pembangunan. Yayasan Obor Indonesia, Jakarta, 2000 .

Amirudin dan Zainul Asikin, Pengantar Metode Peneitian Hukum, Raja Grafindo Persada, Jakarta, 2004.

Andi Hamzah, Hukum Acara Pidana Di Indonesia, Edisi Revisi, Sinar Grafika, Jakarta 1996. , Aspek-aspek Pidana di Bidang Komputer, Jakarta, 1990

Adrian Sutedi, Hak Atas Kekayaan Intelektual, Jakarta, 2009

Budi Agus Riswandi, Hak Kekayaan Intelektual dan Budaya HU, Jakarta, 2009.

Carl Joachim Friedrich, Filsafat Hukum Perspektif Historis, Nuansa Dan Nusamedia, Bandung, 2004.

Departemen Pendidikan Nasional, Kamus Besar Bahasa Indonesia, Edisi III, Jakarta: Balai Pustaka, 2001.

Dominikus Rato, Filsafat Hukum Mencari; Memahami Dan Memahami Hukum, Pressindo, Yogyakarta, 2010.

E. Sumaryono, Etika Profesi Hukum, Kanisius, Yogyakarta, 1995.

Eddy Damian, Simon Butt dan Tomi Suryo Utomo, 2003, Hukum Kekayaan Intelektual Suatu Pengantar, Alumni, Bandung, 2003.

, 2003, Hukum Hak Cipta, Bandung, 2003

Edmon Makarim, Kompilasi Hukum Telematika, Jakarta, 2004

Eikama Hommes, Enscyclopedia der Rechtwetenschappen Algemene Inleiding Tot de Rechtwetenschap, dalam NJB 36/37, 1983.

Endang Purwaningsih, Perkembangan Hukum Intellectual Property Rights, Jakarta, 2006.

E. Utrech Dalam Sudiman Sidabukke, Kepastian Hukum Perolehan Hak Atas Tanah Bagi Investor, Disertasi, Program Pascasarjana Universitas Brawijaya, Malanga, 2007.

Frank Taira Supit, Aspek-Aspek Hukum Dari "Loan Agreement” Dalam Dunia Bisnis Internasional”, Jakarta, 1985.

Friedman, Teori dan Filsafat Hukum, Telaah Kritis atas Teori-teori Hukum, Rajawali Press, Jakarta, 1990.

Gatot Supramono, Hak Cipta dan Aspek-Aspek, Rineka Cipta, 2017. 
Harris Munandar dan Sally Sitanggang, Mengenal HAKI (Hak Kekayaan Intelektual), Hak Cipta, Paten, Merek dan Seluk-Beluknya, Raja Grafindo Persada, Jakarta, 2004.

Hadibroto, S., Sukadam,Sudardjat, Akuntansi Intermediate, PT.Ichtiar Baru Van Hoeve, Jakarta, 1982

H.SKartadjoemena, Substansi Perjanjian GATT/WTO dan MekanismePenyelesaian Sengketa : Sistem Kelembagaan, Prosedur Implementasi, dan Kepentingan Negara Berkembang, Jakarta, 2000.

Hassan Pambudi, Dasar dan Teknik Penerbitan Buku, Sinar Harapan, Jakarta, 1981.

Hapsoro Jayaningprang, Dewan Kerja Sama Ilmu Hukum Belanda dengan Indonesia-Proyek Hukum Perdata, Ujung Pandang, 1999.

H. Man. S. Sastrawidjaja, Bunga Rampai Hukum Dagang, Alumni, Bandung, 2005.

Hendra Tanu Admaja, Hak Cipta Musik atau Lagu, Program Pascasarjana, Fakultas Hukum, Universitas Indonesia, Jakarta, 2003

Henry Campbell, Black's Law Dictionary: Definitions of the Terms and Phrases of American and English Yurisprudence, ancient and Modern, USA: West Publshing Company, 1991.

Henry Soelistyo, Aspek Dalam Perlindungan Hak Cipta, Jakarta, 1997

Jhonny Ibrahim, SH, M.Hum, Teori dan Metodologi Penelitian Hukum

Normatif, Surabaya, 2006

J.M Van Dunne Van Der Burht, Perbuatan Melanggar Hukum, Terjemahan KPH Hapsoro Jayaningprang, Dewan Kerja Ilmu Hukum Belanda Dengan Indonesia-Proyek Hukum Perdata, Ujung Pandang, 2000.

J. Satrio, Hukum Jaminan Hak-hak Jaminan Kebendaan, Citra Aditya Bakti, 1996

, Wanprestasi Menurut KUHPerdata, Doktrin, dan Yurispridensi, Citra Aditya Bakti,Bandung, 2012.

J.P. Fitzgeral, Salmon on Jurisprudece, Sweet and Maswel, London, 1966. Dikutip dari Satjipto Rahardjo, Ilmu Hukum, Bandung: PT. Citra Aditya Bakti, 2000.

Koch. Timothy W. Mac Donald. Sscot, Bank Management

Lili Rasjidi Dan I.B. Wyasa Putra, Hukum Sebagai Suatu Sistem, Remaja Rosdakarya, Bandung, 1993.

Magdalena Sukartono, Buku Sebagai Sarana Pengembangan Kualitas Sumber Daya Manusia, Kanisius, Bandung, 1997.

Mariam Darus Badrulzaman, Mencari Sisem Hukum Benda Nasional, BPHN-Alumni, Bandung, 1983.

M. Yahya Harahap, Hukum Acara Perdata, Citra Aditya Bakti, Bandung, 1999.

---------, Segi-Segi Hukum Perjanjian, Alumni, Bandung, 1986.

Muchsin, Ihtisar Ilmu Hukum, Badan Penerbit Iblam, Jakarta, 2005.

Mukti Fajar ND Dan Yulianto Achmad, Dualisme Penelitian Hukum Normatif Dan Hukum Empiris, Pustaka Pelajar, Yogyakarta, 2010.

Moch. Isnaeni, Pengantar Hukum Jaminan Kebendaan, Revka Petra Media, Surabaya, 2016

----------, Perjanjian Jual Beli, Revka Petra Media, Surabaya, 2015.

---------, Hukum Benda Dalam Burgerlijk Wetboek, Surabaya, 2016.

-, Pijar Pendar Hukum Perdata, Revka Petra Media, Surabaya, 2016.

, Lembaga Jaminan Kebendaan Dalam Burgerlijk Wetboek Gadai Dan Hipotik, Revka Petra Media, Surabaya, 2016.

---------, Selintas Pintas Hukum Perikatan (Bagian Umum), Revka Petra Media, Surabaya, 2017.

-, Seberkas Diorama Hukum Kontrak, Revka Petra Media, Surabaya, 2017.

-,Noktah Ambigu Norma Lembaga Jaminan Fiducia, Revka Petra Media, Surabaya, 2017.

Mochtar Kusumaatmadja Dan Arif Sidharta, Pengantar Ilmu Hukum, Suatu Pengenalan Pertama Ruang Lingkup Berlakunya Ilmu Hukum, Alumni, Bandung, 2004.

O. Notohamidjojo, Masalah Keadilan, Tirta Amerta, Semarang, 1971

Ok. Saidin, Aspek Hukum Hak Kekayaan Intelektual, Jakarta, 2003

Patricial Loughlan, Intelectual Property: Creative and Marketing Rights, LBC Information Services, Australia, 1998.

Peter Mahmud Marzuki, Penelitian Hukum, Yuridika, Volume No. 2 Maret 2001. 
Philipus M. Hadjon, Paper, Yuridika Fakultas Hukum Unair No. 6 Tahun IX November-Desember 1994.

---------, Perlindungan Hukum Bagi Rakyat Indonesia, Surabaya: PT. Bina Ilmu, 1987.

Purwahid Patrik, Hukum Perdata II, Universitas Diponegoro, Semarang, 1988.

-, Dasar-dasar Hukum Perikatan (Perikatan yang lahir dari perjanjian dan dari undang-undang), Mandar Maju, Bandung, 1994.

Rachmadi Usman, Hukum HAKI : Pelindungan dan Dimensi Hukumnya,

Bandung, 2003.

R. Ali Ridho, Hukum Dagang, Alumni, Bandung, 1992.

Rd. Hasan nata Permana, Bentuk Hukum Perusahaan, Bandung, 1952.

Riduan Syahrani, Rangkuman Intisari Ilmu Hukum, Citra Aditya Bakti, Bandung, 1999.

Saifudin Noorhadi, Disertasi, Program Pascasarjana, Universitas Brawijaya, Malang, 2005.

Salim HS, Perkembangan Hukum Jaminan di Indonesia, Rajawali Pers, Jakarta.

Satjipto Rahardjo, IImu Hukum, Citra Aditya Bakti, Bandung, 2000.

Satrio, Hukum Perikatan, Tentang Hapusnya Perikatan, Buku I, Citra Aditya Bakti, Bandung, 1996.

Saunders, Antony, Garnett M. Millon., (2008), Financial Institutions Management : A Risk Management Approach ,Sixth Edition, Mc Graw-Hill International Edition, New York.

Setiawan, 1979. Pokok-pokok Hukum Perikatan, Bina Cipt, Bandung, 1979.

Syafrinaldi, Hukum Tentang Perlindungan Hak Milik Intelektual Dalam Menghadapi Era Globalisasi, Jakarta, 2010.

Soerjono Soekanto, Hukum Adat Indonesia, Rajawali, Jakarta, 1983.

Soekanto Soerjono, Pengantar Penelitian Hukum, Jakarta, 1986.

Soetanto Soepiadhy, Keadilan Hukum, Surabaya Pagi, 28 Maret 2012.

---------, Kemanfaatan Hukum, Surabaya Pagi, Kamis, 12 April 2012.

---------, Kepastian Hukum, Surabaya Pagi, Rabu, 4 April 2012.

Sonny Keraf, Etika Bisnis Tuntunan Dan Relevansinya, Kanisius, Yogyakarta, 1998.

Sri Mamuji, Penelitian Hukum Normatif, Rajawali Press, Jakarta, 1990.

Sri Soedewi Masjchoen Sofwan, Hukum Jaminan di Indonesia, Pokok-pokok Hukum Jaminan dan Jaminan Perorangan, BPHN dan Liberty, Yogyakarta, 1980.

Subekti, Hukum Perjanjian, Intermasa, Jakarta, 1991, h. 1.

---------, Jaminan-jaminan untuk Pemberian Kredit Menurut Hukum Indonesia, Alumni, Bandung, 1978.

, Kitab Undang-Undang Hukum Perdata, Pradnya Paramita, Jakarta, 2005.

Sudargo Gautama dan Rizawanto Winata, Pembaharuan Undang - Undang Hak Cipta, Bandung, 1997

Sudiman Sidabukke, Kepastian Hukum Perolehan Hak atas Tanah bagi Investor, Disertasi, Program Pascsarjana Universitas Brawijaya, Malang, 2007.

Suherman, Ade Maman, Aspek Hukum Dalam Teknologi, Jakarta, 2002.

Suyud Margono, Hak Kekayaan Intelektual Komentar atas Undang-undang Rahasia Dagang. Desain Industrti, Desain Tata Letak Sirkuit Terpadu, Jakarta, 2001.

Suwarno Wiji, Perpustakaan \& Buku Wacana \& Penerbitan, Ar-Ruzz Media, Yogyakarta, 2011.

Sutarno, Aspek-Aspek Hukum Perkreditan Pada Bank. Jakarta. 2010.

Tamotsu Haozumi, Asian Copyright Handbooks, Jakarta, 2006.

Theo Huijbers, Filsafat Hukum Dalam Lintasan Sejarah, Yogyakarta, 1995

Uma Barrung, Asas Kebebasan Berkontrak Dan Perlindungan Konsumen Pada Perjanjian Kredit Makalah Dialog Sehari PP-INI Dengan Perbanas, Jakrta 2002.

W.J.S. Poerwadarminta, Kamus Umum Bahasa Indonesia, Balai Pustaka, Jakarta, 1976.

Widjaja Gunawan, Lisensi, Raja Grafindo Persada, Jakarta, 2001. 
Zaim Saidi, Selamat Datang WTO, Republika, Jakarta, 1995.

\section{Peraturan Perundang-undangan:}

Undang-Undang Dasar Negara Republik Indonesia Tahun 1945

Undang-undang Nomor 7 Tahun 1994 tentang Pengesahan Agreement Establishing the World Trade Organization (WTO).

Undang-undang Nomor 17 Tahun 2006 tentang Perubahan atas Undang-Undang Nomor 10 Tahun 1995 tentang Kepabeanan.

Undang-Undang Nomor 28 Tahun 2014 tentang Hak Cipta.

Undang-undang Nomor 15 Tahun 2001 tentang Merek.

Undang-undang Nomor 13 Tahun 2016 tentang Hak Paten.

Keputusan Presiden RI Nomor 15 tahun 1997 tentang Pengesahan Paris Convention for the Protection of Industrial Property dan Convention Establishing the World Intellectual Property Organization.

Keputusan Presiden RI Nomor 17 Tahun 1997 tentang Pengesahan Trademark Law Treaty.

Keputusan Presiden RI Nomor 18 Tahun 1997 tentang Pengesahan Berne Convention for the Protection of Literary and Artistic Works.

Keputusan Presiden RI Nomor 19 Tahun 1997 tentang Pengesahan WIPO Copyrights Treaty.

\section{Internet:}

https://dhiasitsme.wordpress.com/2012/03/31/hak-atas-kekayaan-intelektual-haki/.

http://www.kemenperin.go.id/.

https://rarabebyuchul.wordpress.com/2013/05/24/pengertian-hak-cipta/.

http://www.hukumonline.com/klinik/detail/cl755/royalti-hak-cipta.

http://repository.usu.ac.id/bitstream/123456789/29107/3/.

https://shareshareilmu.wordpress.com/2012/02/05/wanprestasi-dalam-perjanjian/.

https://penerbitdeepublish.com/cara-menerbitkan-buku-penerbit-buku-g009

http://www.kompasiana.com/abu_fathan/mengintip-hitung-hitungan-royalti-penulis-

buku_550bb1af813311c42ab1e1be. 